\title{
The Intersection of Aging and Cancer
}

\author{
El-Tawil AM* \\ University Hospital Birmingham, UK
}

Submission: September 17, 2017; Published: November 27, 2017

*Corresponding author: El-Tawil AM, University Hospital Birmingham. United Kingdom. B15 2GW Fax: 00441214466220 ;

Email: atawil20052003@yahoo.co.uk

Abstract

Life expectancy increases. Many developed countries are experiencing an increase in older individuals, both in terms of absolute numbers and by means of proportion of the total population. Ageing is fundamental factor for the development of cancer. The incidence of cancer rises intensely with age, most likely due to a build-up of risks for specific cancers that increase with age. The overall risk accumulation is conjoined with the tendency for cellular repair mechanisms to be less effective as person grows older.

Screening aims to identify individuals with abnormalities suggestive of a specific cancer or pre-cancer who have not developed any symptoms and refer them promptly for diagnosis and treatment.

Keywords: Elderly; Cancer; Chronic-non-infectious diseases; Organ impairment; Autoimmune diseases; Trace elements and metals

\section{Introduction}

As life expectancy increases, many countries are experiencing an increase in older individuals, both in terms of absolute numbers and as a proportion of the total population. In 1999, for example, in every day, more than 6,000 Americans celebrated their 65th birthday [1].

a. In 2004, in the United States, there were an estimated 60,800 centenarians [2].

b. In the same year, one out of every eight people (approximately $12.4 \%$ of the population) was an older person [3].

c. Since 1900, the 65 and older population had doubled three times [4].

d. During the same century, the population of oldest old Americans (those aged 85 and older) grew from just over 100,000 to 4.2 million [5].

e. The number of people aged 100 and older increased $36 \%$ between 1990 and 2003growing from 37,306 to 50,639 [3].

Excessive zinc loss is a common complication of different organs' impairment in the ageing population and as a result of longstanding common chronic non-infectious and autoimmune diseases that are prevalent in the ageing population (Table 1). Screening programmes can be effective for detecting cancers when appropriate tests are used, implemented effectively and properly linked to other steps in the screening program.
Table 1: Major Causes of Zinc Deficiency in the elderly.

\begin{tabular}{|c|}
\hline Inadequate intake \\
\hline (1). Enteral alimentation \\
\hline (2). Haemolytic anaemia \\
\hline (3) Intravenous alimentation \\
\hline Malabsorption \\
\hline (4) During intravenous alimentation \\
\hline (5) Malabsorption syndrome: \\
\hline (a). Liver dysfunction \\
\hline (b). Pancreatic dysfunction, \\
\hline (C)Inflammatory bowel diseases \\
\hline (d). short bowel syndrome \\
\hline (5) Excessive loss \\
\hline (a). Intestinal fistula, \\
\hline (b). Increased urinary elimination: \\
\hline (C)Prolonged intravenous alimentation \\
\hline (d)Liver cirrhosis \\
\hline (e). Diabetes mellitus \\
\hline (f). Renal disease \\
\hline $\begin{array}{l}\text { (g). Shortage of nutrient intake enhanced catabolism (surgery, trauma, } \\
\text { infection, etc...), }\end{array}$ \\
\hline (h)Diuretics \\
\hline (i).Haemodialysis \\
\hline
\end{tabular}




\section{Zinc deficiency and gastrointestinal cancer}

In a published report in 2005, Boz A et al. [6] assessed the plasma levels of zinc, copper and ceruloplasmin in 25 patients who underwent surgery for gastrointestinal cancers and compared the results with those of 20 healthy controls. The blood samples were taken preoperatively from the patients. In this study, levels of $\mathrm{Cu}$ and Zn were defined with calorimetric measure and ceruloplasmin levels were measured with immunohistochemical assay. The decrease in $\mathrm{Zn}$ levels and the increases in the levels of both of ceruloplasmin and $\mathrm{Cu}$, in patients with gastrointestinal cancers were found to be significant $(\mathrm{p}<0.001, \mathrm{p}=0.014$ and $\mathrm{p}=0.019$, respectively) when compared to those of the control group. In the patient group, the correlations between serum $\mathrm{Cu}$ and serum ceruloplasmin proved to be significant $(r=991, p<0.001)$. The $\mathrm{Cu} / \mathrm{Zn}$ ratio, when compared with $\mathrm{Zn}$, ceruloplasmin and $\mathrm{Cu}$, showed significant results $(\mathrm{r}=0$. $562, r=0.500, r=0.506, p<0.001)$.

These findings were positively supporting the earlier published results [7]. In the latter study, the serum levels of $\mathrm{Cu} / \mathrm{Zn}$ SOD were significantly elevated in gastric cancer patients compared with healthy controls.

\section{Discussion}

Deficiency of zinc has multiple carcinogenic consequences, including effects on mutagenesis, DNA repair, DNA synthesis, cell proliferation, apoptosis and differentiation, and on the cellular anti-oxidant balance [8]. To the contrary, zinc replenishment exerts preventive effects on mutagenesis and cell transformation by at least three mechanisms:

a. Zinc is a potent anti-oxidant agent, in particular through its capacity to bind and protect sulfhydryls in proteins from the drastic attacks;

b. Zinc is a co-factor, which regulates the catalytic activity of over 300 enzymes belonging to all major classes of mammalian enzymes; and

c. Zinc binds to specific residues in protein and stabilizes protein tertiary and quaternary structures [8-13].

In addition, the antioxidant roles of zinc include the removal of superoxide ions by superoxide dismutase impairing hydroxyl ion formation by redox-active transition metals like copper and iron [14] and the regulation of expression and activity of metallothioneins ( a major class of metal and radical buffer proteins involved in many stress responses and detoxification reactions) $[8,15]$.

Not only the development of malignant tumours is closely linked to the deficiency of zinc [16] but the activity of the cancer is also directly linked to the severity of the zinc deficiency [17]. Thence, the improvement in the life expectation must be accompanied with the appropriate plans for improving the elderly patients' care and their quality of life. To that effect, the present study emphasises on the crucial importance of conducting regular screening for the deficiency of zinc in the elderly and on its replenishment.

\section{References}

1. Alliance for Aging Research (1999) Independence for Older Americans: An investment for our nation's future. Alliance for Aging Research, Washington, USA.

2. http://www.silverbook.org/wp-content/uploads/2015/06/TheSilver-Book_Chronic-Disease-and-Medical-Innovation-in-an-AgingNatio.

3. Administration on Aging (2004) A Profile of Older Americans: 2004: United States Department of Health and Human Services, Washington, USA.

4. Fried land, Robert B, Laura Summer (2005) Demography Is Not Destiny, Revisited: Center on an Aging Society, Georgetown University, Washington, USA.

5. Federal Interagency Forum on Aging-Related Statistics (2004) Older Americans 2004: Key indicators of well-being. U.S. Government Printing Office, Washington, USA.

6. Boz A, Evliyaoğlu O, Yildirim M, Erkan N, Karaca B (2005) The value of serum zinc, copper, ceruloplasmin levels in patients with gastrointestinal tract cancers. Turk J Gastroenterol 16(2): 81-84.

7. Lin Y, Kikuchi S, Obata Y, Yagyu K (2002) Tokyo research group on prevention of gastric cancer. Serum copper/zinc superoxide dismutase (Cu/Zn SOD) and gastric cancer risk: a case-control study. Jpn J Cancer Res 93(10): 1071-1075.

8. Ho E (2004) Zinc deficiency, DNA damage and cancer risk. Journal of Nutl Bioch 15: 572-578.

9. Pradad AS (1998) Zinc deficiency in humans: A neglected problem. J Am Coll Nutr 17: 542- 543.

10. Prasad AS, Kucuk O (2002) Zinc in cancer prevention. Cancer Metastasis Rev 21(3-4): 291- 295.

11. Prasad AS (2003) Zinc deficiency. Br Med J 326: 409-410.

12. Fong LY, Mancini R, Nakagawa H, Rustgi AK, Huebner K (2003) Combined cyclin D1 overexpression and zinc deficiency disrupts cell cycle and accelerates mouse forestomach carcinogenesis. Cancer Res 63(14): 4244-4252.

13. Washabaugh MW, Collins KD (1986) Dihydroorotase from Escherichia coli. Sulfhydryl group- metal ion interactions. J Biol Chem 261(13): 5920-5929.

14. Conte D, Narindrasorasak S, Sarkar B (1996) In vivo and In vitro iron replaced zinc finger generates free radicals and causes DNA damage. J Biol Chem 271: 5125- 5130

15. Malemud CJ (2006) Matrix metalloproteinases (MMPs) in health and disease: an overview. Front Biosc 1(11): 1696-1701.

16. Mir MM, Dar NA, Salam I, Malik MA, Lone MM, et al. (2007) Studies on association between copper excess, Zinc deficiency and TP53 mutations in esophageal squamous cell carcinoma from kashmir valley, India-A high risk area. Int J Health Sci (Qassim) 1(1): 35-42.

17. Adaramoye OA, Akinloye O, Olatunji IK (2010) Trace elements and Vitamin E status in Nigerian patients with prostate cancer. Afr Health Sci 10(1): 2-8. 


\section{Your next submission with Juniper Publishers will reach you the below assets}

- Quality Editorial service

- Swift Peer Review

- Reprints availability

- E-prints Service

- Manuscript Podcast for convenient understanding

- Global attainment for your research

- Manuscript accessibility in different formats ( Pdf, E-pub, Full Text, Audio)

- Unceasing customer service

Track the below URL for one-step submission https://juniperpublishers.com/online-submission.php 